\title{
Evaluation of Water Quality Based on Macrozoobenthos as a Bioindicator in the Four Springs of Wana Wiyata Widya Karya Tourism Area, Cowek Village, Purwodadi District, Pasuruan Regency
}

\author{
Mas Khoirud Darojat ${ }^{*}$, Nia Kurniawan, Catur Retnaningdyah \\ Department of Biology, Faculty of Mathematics and Natural Sciences, University of Brawijaya, Malang, Indonesia
}

\begin{abstract}
The purpose of this study was to determine water quality based on the physicochemical of water and biotic indices from macrozoobenthos in four springs in the Wana Wiyata Widya Karya tourism area, Cowek Village, Pasuruan. Identification and calculation of macrozoobenthos were used to determine the macrozoobenthos community structure and some biotic indices (ASPT, FBI, EPT indices, and water quality index) as bioindicators of water quality. Water quality grouping based on physicochemical of water and biotic indices was analyzed using Cluster Analysis, and Biplot. The results showed that several physical-chemical parameters of water observed had values exceeding water quality standards for drinking water raw materials (BOD, DO, temperature and $\mathrm{pH}$ ), based on Government Regulations No. 82 of 2001. Based on the NSF-Water Quality Index, water quality in four springs in the Wana Wiyata Widya Karya tourism area is in good category (72.77-88.37), which indicates that the waters are not contaminated with organic matter. Water quality based on the macrozoobenthos diversity index value indicates the category of moderate to mild contamination (H value 1.40-1.97). The Bray-Curtis similarity index resulted in a high level of similarity between of Alang-Alang and Sumber Bendo in 86.49\%.
\end{abstract}

Keywords: biotic index, macrozoobenthos, springs, Wana Wiyata Widya Karya, water quality.

\section{INTRODUCTION}

One of the water tourism destinations in Pasuruan is its spring area. Spring is an important part of tourist destinations because of its role as a source of domestic water, irrigation, and drinking water. The contamination of the spring will affect the flow of the spring. The quality of water influenced by the condition of the surrounding environment and its management by humans [1]. One effort that must be made in maintaining the availability of clean water is to preserve the spring by means of conservation. Groundwater conservation is a way to protect and preserve the existence, conditions, and environment of groundwater to maintain water availability in terms of quality and quantity (discharge) of groundwater.

The community in Cowek Village seeks to improve the quality and discharge of water in the springs of Cowek Village by planting various types of local plants around the spring of Wana Wiyata Widya Karya. These efforts have been carried out for many years, and now there is an increase in the discharge of springs in Cowek Village. Water flows from the spring of Wana Wiyata Widya Karya is now used by the people of Cowek Village

\footnotetext{
" Correspondence address:

Mas Khoirud Darojat

Email : drjatsuro92@gmail.com

Address : Dept. Biology, University of Brawijaya, Veteran Malang, Malang 65145
}

to fulfill their daily needs, such as drinking water, cooking, washing, irrigating agricultural land, and fisheries. The spring also used as a tourist area based on water conservation.

The success of the efforts made by the Cowek Village community to preserve the spring can be found by evaluating the quality and quantity of water in several springs in Cowek Village. One way to evaluate the quality of water is to measure the physical, chemical, and biological parameters of an aquatic ecosystem [2]. Biological parameters were known by identifying the community structure of macrozoobenthos. Macrozoobenthos are considered sensitive to changes in water quality [3]. The use of biological parameters is very important to show the relationship between biotic and non-biotic environments.

Given the importance of the spring role to meet the needs of the community, as well as a tourist object based on water conservation, a study is needed. The study aimed to evaluate the water quality based on the physicochemical of water and biotic indices from macrozoobenthos of the spring in the village. Water quality evaluation carried out by monitoring the physical and chemical properties of water, and several biotic indices from macrozoobenthos as bioindicators to describe water quality in the tourism area. The results of the research can be used as a basis for making guidelines in water management. 


\section{MATERIAL AND METHOD \\ Study Area}

This research is descriptive exploratory, carried out in December 2017 to February 2018 in four springs of Cowek Village, Purwodadi District, Pasuruan Regency (Fig. 1). Data processing was carried out at the Ecology Laboratory, Biology Department, Faculty of Mathematics and Natural Sciences, Brawijaya University, Malang.

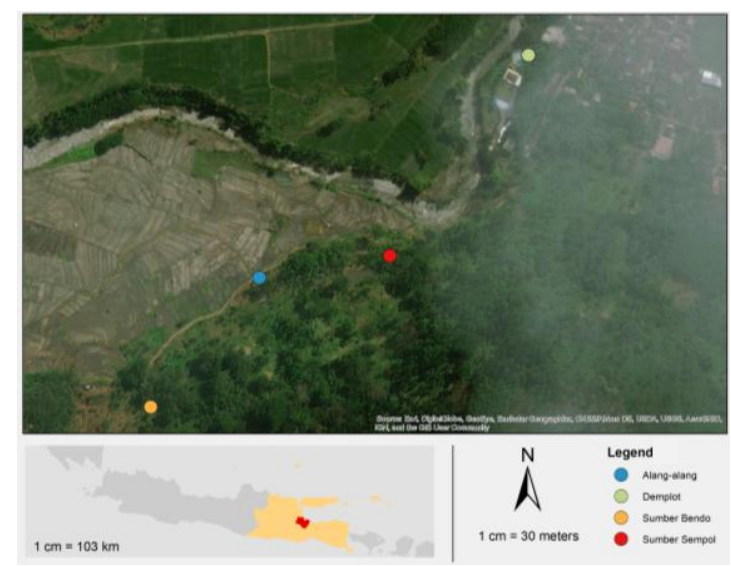

Figure 1. Location of spring in the village of Cowek of Wana Wiyata Widya Karya

\section{Data Collection}

Water and macrozoobenthos sampling carried out at four spring stations with different types of surrounding communities. There was secondary forest (Sumber Bendo), Trembesi forest (Sumber Sempol), Alang-Alang, and Demplot (Wana Wiyata Widya Karya tourism area). Sampling has been repeated three times for each spring. The water samples analyzed for their physicochemical parameters including measurements of temperature, $\mathrm{pH}$, discharge, DO, BOD, conductivity, and turbidity, with the method as shown in Table 1.

Table 1. Methods and tools used in measuring physical chemical parameters

\begin{tabular}{lll}
\hline Parameter & Tools & Method \\
\hline Temperature $\left({ }^{\circ} \mathrm{C}\right)$ & Thermometer digital & Potentiometric \\
Conductivity $\left(\mu \mathrm{S} . \mathrm{cm}^{-1}\right)$ & Conductivity-meter & Potentiometric \\
Turbidity $(\mathrm{NTU})$ & Turbidity-meter & Light refraction \\
Debit $\left(\mathrm{L} . \mathrm{s}^{-1}\right)$ & Bucket, stopwatch & Visual \\
DO $\left(\mathrm{mg} . \mathrm{L}^{-1}\right)$ & Titration & Winkler method \\
pH & pH meter & Potentiometric \\
BOD $\left(\mathrm{mg} . \mathrm{L}^{-1}\right)$ & Titration & Winkler method \\
\hline
\end{tabular}

\section{Data Analysis}

The physicochemical parameters analyzed using the water quality index of the National Sanitation Foundation Water Quality Index (NSFWQI) [4]. Macrozoobenthos was identified and it's calculated the number of individuals per type then used for the determination of community structure and several biotic indexes including ASPT, FBI, EPT, diversity index (Margalef, Simpson, Shannon-Wiener) as follows:

a. Diversity index $\left(H^{\prime}\right)$

The formula used is the diversity index of Shanon-Wiener [2]:

$$
H^{s}=-\sum_{i=1}^{s} p i \ln p i
$$

\section{Description:}

$\mathrm{H}^{\prime}=$ diversity index Shanon-Wiener

$\mathrm{Pi}=\mathrm{ni} / \mathrm{N}$ (species proportion in the-i)

$\mathrm{ni}=$ number of individual of each species in the-i

$\mathrm{N}=$ total number of individual

$\mathrm{S}=$ number of species

\section{b. Evenness Index (E)}

The evenness index shows the composition of individuals of each species in a community. We use the formula of the evenness index below [5].

$$
\mathrm{E}=\frac{H^{\prime}}{H \max }
$$

\section{Description:}

$\mathrm{E} \quad=$ evenness index

$\mathrm{H}^{\prime} \quad$ = diversity index

$\mathrm{H} \max =\log 2 \mathrm{~S}$

$S \quad=$ number of species

c. Dominance Index

The Simpson dominance index used to determine the degree of dominance by certain types of macrozoobenthic organisms [6].

Description:

$$
\mathrm{C}=\sum[\mathrm{ni} / \mathrm{N}]^{2}
$$

$\mathrm{C}=$ Simpson dominance index

ni $=$ Number of individuals per species

$\mathrm{N} \quad=$ Total number of individuals

i $=1,2, \ldots \ldots$ and so on

d. Species Richness

Species richness index is the total number of species in a community. We used the calculation of Margalef [7].

$$
D M g(\text { Margalef })=\frac{S-1}{\ln N}
$$

Description:

$\mathrm{N}=$ total of individual per all recorded species $\mathrm{S}=$ number of species

\section{e. Species Density}

Species density (Ki) defined as the number of individuals of macrozoobenthic organisms per unit area $\left(\mathrm{m}^{2}\right)$. We used Odum's [6] formula to calculate the species density as follows. 


$$
\mathrm{K}=\frac{10000}{B \times n} \times a
$$

Description:

$\mathrm{K}=$ macrozoobenthos density (individual $\mathrm{m}^{-2}$ )

$A=$ number of macrozoobenthos individual of species in the-i

$B=$ wide of mouth opening of surber net $\left(\mathrm{cm}^{2}\right)$

$10000=$ conversion value from $\mathrm{cm}^{2}$ to $\mathrm{m}^{2}$

$\mathrm{n}=$ number of sampling repetition

f. ASPT

The value of ASPT is obtained by classifying macrozoobenthos organisms that have been identified by family, then given a score based on the Biological Monitoring Working Party [8]. Scoring of macrozoobenthos was carried out in each station by summed the macrozoobenthos scores. BMWP values obtained from each station divided by the number of macrozoobenthos groups to obtain ASPT values.

g. The Family Biotic Index (FBI)

$\mathrm{FBI}$ introduced by Hilsenhoff in 1988 is used to detect organic pollution based on a tolerant and intolerant family level. The calculation of the biotic index is as follows [9].

$$
F B I=\sum_{i=1}^{i=n} \frac{x i \cdot t i}{N}
$$

Description:

$\mathrm{i}$ = sequence of family groups that make up the macrozoobenthos community

$x i=$ the number of individuals in the-i family group

$\mathrm{ti}=$ the level of tolerance of family in the $i$

$\mathrm{N}=$ the number of all individuals composing the macrozoobenthos community

h. EPT

Ephemeroptera, Plecoptera, Trichoptera (EPT) index describes the abundance of taxa in groups of aquatic insects that are sensitive to pollution. The EPT index calculation is by identifying and classifying organisms at the order level, then calculating the percentage of the number of individual orders of Ephemeroptera, Plecoptera, Trichoptera from the total number of individuals found [10].

Grouping of springs based on water quality determined through Cluster and Biplot Analysis using the Bray-Curtis similarity index [2]. Cluster and Biplot analysis results presented in the form of a dendrogram by using Minitab software.

\section{RESULT AND DISCUSSION}

Water Quality Characteristics Based on PhysicalChemical Parameters

The characteristics of water quality in the springs in Wana Wiyata Widya Karya tourism area Cowek Village are quite diverse (Table 2). It influenced by land-use factors around the spring. Measurement of physical-chemical parameters in each spring produced different values, although the fluctuations were not significant. The temperature values at each station were relatively the same, ranged from $26-27^{\circ} \mathrm{C}$. It was because temperature measurements were carried out at almost the same time. Besides, because the four stations are springs or upstream areas, they have a relatively constant and lower annual temperature [11].

The highest conductivity value found in the Sempol Source spring, which was equal to $250 \pm 26 \mu \mathrm{S} . \mathrm{cm}^{-1}$ and the lowest was in Sumber Bendo $\left(207 \pm 2 \mu \mathrm{S} . \mathrm{cm}^{-1}\right)$. The high value of conductivity water showed a higher content of dissolved salts that can be isolated. The measurement of electrical conductivity value to identify water quality used two analogies, namely, the smaller the value of the electrical conductivity means the purer the water, and the better the water quality [20].

Table 2. Physical Chemical Parameters of Springs at Wana Wiyata Widya Karya Tourism Area, Village of Cowek

\begin{tabular}{lccccc}
\hline Parameters & $\begin{array}{c}\text { Demplot } \\
\text { Spring }\end{array}$ & $\begin{array}{c}\text { Sumber Sempol } \\
\text { Spring }\end{array}$ & $\begin{array}{c}\text { Alang-alang } \\
\text { Spring }\end{array}$ & $\begin{array}{c}\text { Sumber Bendo } \\
\text { Spring }\end{array}$ & $\begin{array}{c}\text { Water Quality } \\
\text { Standard Class I* }\end{array}$ \\
\hline Temperature $\left({ }^{\circ} \mathrm{C}\right)$ & $26 \pm 0.0$ & $27 \pm 0.0$ & $27 \pm 0.0$ & $26.5 \pm 0.5$ & $28 \pm 3$ \\
Conductivity $\left(\mu \mathrm{S} . \mathrm{cm}^{-1}\right)$ & $241 \pm 14$ & $250 \pm 26$ & $212.5 \pm 1.5$ & $207 \pm 2$ & - \\
Turbidity $(\mathrm{NTU})$ & $9.83 \pm 7.58$ & $26.41 \pm 25.89$ & $2.53 \pm 0.89$ & $6.19 \pm 1.89$ & 5 \\
Debit $\left(\mathrm{L} . \mathrm{s}^{-1}\right)$ & $1.9 \pm 0.52$ & $0.97 \pm 0.09$ & $1.85 \pm 0.05$ & $1.98 \pm 0.08$ & - \\
DO $\left(\mathrm{mg} . \mathrm{L}^{-1}\right)$ & $6.40 \pm 1.28$ & $7.63 \pm 1.56$ & $7.28 \pm 2.32$ & $8.24 \pm 1.84$ & $\geq 6$ \\
pH & $6.01 \pm 0.29$ & $6.45 \pm 0.45$ & $7.23 \pm 0.07$ & $6.71 \pm 0.09$ & $6-9$ \\
BOD $\left(\mathrm{mg} . \mathrm{L}^{-1}\right)$ & $1.94 \pm 0.22$ & $1.50 \pm 0.08$ & $1.78 \pm 0.14$ & $0.56 \pm 0.36$ & $\leq 2$ \\
\hline
\end{tabular}

*Government Regulations No. 82 in 2001 about Management of Water Quality and Controlling Water Contamination 
The highest turbidity was also found in the Sumber Sempol spring with a value of $26.41 \pm$ 25.89 NTU. The flow of springs at Sumber Sempol was nearby to the rice fields, so it is widely used by residents to wash their planting equipment. As a result, the flow of water becomes more turbid compared to other stations. Based on Government Regulations No. 82 Year 2001, only the Alang-Alang spring met water quality standards with a value of less than 5 NTU, while the other three springs have a value of more than 5 NTU. Increasing turbidity values will affect the concentration of light into the body of water and inhibit photosynthesis. This condition causes a decrease in water productivity [12]. The low value of turbidity in Alang-alang springs due to the absence of recreational activities occurring in the area. Alang-Alang is located with some distance from the tourist area of the Demplot spring, it takes 10-15 minutes on foot from the Demplot spring. There is no development in the area, so this area is less attractive for tourists to visit.

The results of the measurement of $\mathrm{pH}$ values at all four locations ranged from 6-7.23. The lowest $\mathrm{pH}$ was in the Demplot spring, while the highest is in the Alang-Alang spring. Based on the measurement of $\mathrm{pH}$ value, the four springs met water quality standards, with the value of $\mathrm{pH}$ ranging from 6-9. Chemical and organic pollution and nutrient status of waters are often the cause of drastic fluctuations in $\mathrm{pH}$ values. The presence of carbonates, bicarbonates, and hydroxides will increase the alkalinity of water. Meanwhile, the presence of acids in free minerals and carbonic acid will increase the acidity of water [13]. AlangAlang springs have a more open canopy compared to other springs, so that sunlight can directly penetrate the waters. The station with the highest water discharge was the Sumber Bendo spring.

The highest DO value was in the Sumber Bendo spring, which ranged from $8.24 \pm 1.84$ $\mathrm{mg} \cdot \mathrm{L}^{-1}$ while the lowest was the Demplot spring with a value of $6.40 \pm 1.28 \mathrm{mg} \cdot \mathrm{L}^{-1}$. Conversely, the spring with the lowest BOD value was the Sumber Bendo spring, with a value of $0.56 \pm 0.36$ $\mathrm{mg} . \mathrm{L}^{-1}$, while the highest was in the Demplot spring, which was equal to $1.94 \pm 0.22 \mathrm{mg} \cdot \mathrm{L}^{-1}$. Based on the DO and BOD values, the four springs met the water quality standard, with DO values greater than 6 and BOD less than 2 . Dissolved oxygen in the waters influenced by the decomposition of organic matter and oxidation of inorganic materials [13]. The process of decomposition of inorganic materials in large quantities in the waters will absorb oxygen in water, thereby reducing the amount of dissolved oxygen. The high DO value and low BOD value indicate that the spring is not polluted by organic waste disposal.

Based on measurements of physicochemical parameters of water, only the value of turbidity has not met water quality standards. Meanwhile, the values of dissolved oxygen (DO), BOD, temperature, and $\mathrm{pH}$ (Table 2 ) in all four springs have met the class I water quality standards based on Government Regulations No. 82 year 2001 [19]. It showed that the water in the spring can be used for raw water for drinking water or other designation, which requires water quality for daily use.

Demplot spring is a water ecotourism area that is visited by many tourists. Many tourists who visit only to see natural beauty, recreational activities, swimming, to take part in activities to preserve the spring, through tree planting or nursery management. Alang-Alang springs have the potential to be developed into water tourism, especially in terms of drinking water management, because the water quality has standard class I, according to Government Regulation No. 82 of 2001. The development of spring management will make it more attractive for tourists, because they not only can bathe and swim, but they can see the process of managing drinking water. It can also be a means of socialization to tourists, so they want to help protect and maintain the springs.

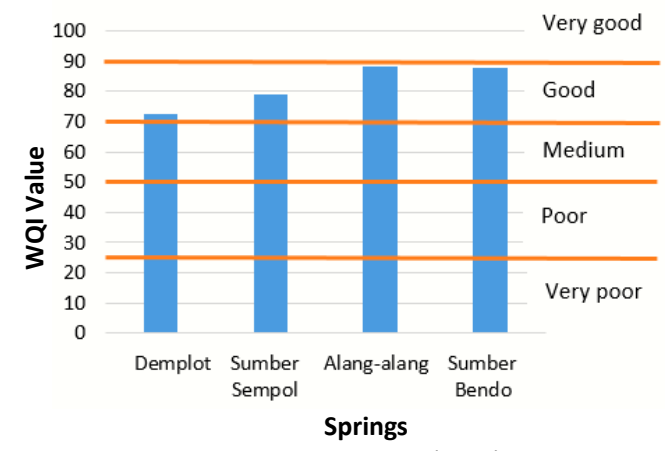

Figure 2. Water Quality Index (WQI) values and the category of water quality in each spring

The National Sanitation Foundation Water Quality Index (NSF-WQI) is determined to assess the level of water quality of a water body. This water quality index is based on nine parameters, which include BOD, DO, nitrate, total phosphate, temperature, turbidity, TDS, $\mathrm{pH}$, and Fecal Coliform [14]. Determination of the NSF-WQI in 
the study used modifications so that only five water physical-chemical parameters were used DO, pH, BOD, temperature changes, and turbidity. The calculated WQI values ranged from 72.77 to 88.37 (Fig. 2). The category of WQI values in the four springs showed that the water quality was at a good level. It indicated that water at the research site was not contaminated with organic matter.

\section{Water Quality Based on Macrozoobenthos as Bioindicator}

We found 26 species of macrozoobenthic organisms which represented 24 families (Table 3 ). The order of Sorbeoconcha (Melanoides tuberculata) from the Thiaridae family is an order with the highest abundance. The group of these animals was always found in each research location as shown in (Fig. 3).

Subsequent high abundance was also found in the Baetidae family and was followed by Simuliidae. Baetidae was quite abundant in all three locations, considering the data collection processes were carried out during the rainy season.

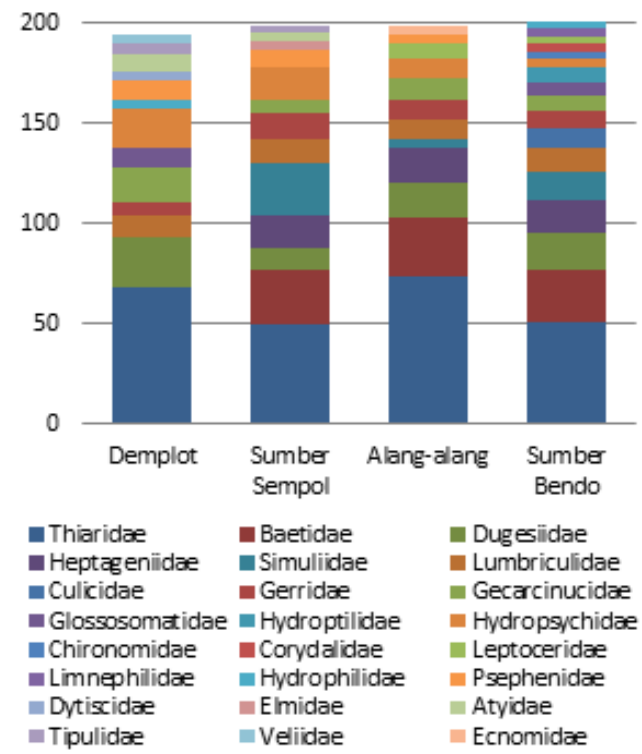

Figure 3. Important Value Index of the macrozoobenthos family found in each spring

Table 3. Macrozoobenthos was found in the spring at Wana Wiyata Widya Karya Tourism Area, Village of Cowek

\begin{tabular}{|c|c|c|c|c|c|c|c|}
\hline No & Order & Family & Genus & Demplot & $\begin{array}{l}\text { Sumber } \\
\text { sempol }\end{array}$ & $\begin{array}{l}\text { Alang- } \\
\text { alang }\end{array}$ & $\begin{array}{l}\text { Sumber } \\
\text { bendo }\end{array}$ \\
\hline 1 & Coleoptera & Psephenidae & Psephenus & + & + & + & - \\
\hline 2 & Coleoptera & Dytiscidae & Copelatus & + & - & - & - \\
\hline 3 & Coleoptera & Hydrophilidae & Hydrophilini & + & - & - & - \\
\hline 4 & Coleoptera & Elmidae & Pharceonus & - & + & - & - \\
\hline 5 & Coleoptera & Hydrophilidae & Hydrophilus & - & - & - & + \\
\hline 6 & Decapoda & Gecarcinucidae & Parathelphusa & + & + & + & + \\
\hline 7 & Decapoda & Atyidae & Paratya & + & + & - & - \\
\hline 8 & Diptera & Tipulidae & Prionocera & + & + & - & - \\
\hline 9 & Diptera & Simuliidae & Simulium & - & + & + & + \\
\hline 10 & Diptera & Culicidae & Aedes & - & - & - & + \\
\hline 11 & Diptera & Chironomidae & Chironomus & - & - & - & + \\
\hline 12 & Ephemeroptera & Baetidae & Baetis & - & + & + & + \\
\hline 13 & Ephemeroptera & Heptageniidae & Ecdyonurus & - & + & + & + \\
\hline 14 & Hemiptera & Gerridae & Gerris & + & + & + & + \\
\hline 15 & Hemiptera & Veliidae & Microvelia & + & - & - & - \\
\hline 16 & Megaloptera & Corydalidae & Chauliodes & - & - & - & + \\
\hline 17 & Oligochaeta & Lumbriculidae & Lumbriculus & + & + & + & + \\
\hline 18 & Sorbeoconcha & Thiaridae & $\begin{array}{l}\text { Melanoides } \\
\text { tuberculata }\end{array}$ & + & + & + & + \\
\hline 19 & Sorbeoconcha & Thiaridae & $\begin{array}{l}\text { Melanoides } \\
\text { granifera }\end{array}$ & + & + & + & - \\
\hline 20 & Trichoptera & Glossosomatidae & Glossosomatidae & + & - & - & + \\
\hline 21 & Trichoptera & Leptoceridae & Leptoceridae & - & - & + & + \\
\hline 22 & Trichoptera & Ecnomidae & Daternomina & - & - & + & - \\
\hline 23 & Trichoptera & Hydroptilidae & Ithytrichia & - & - & - & + \\
\hline 24 & Trichoptera & Limnephilidae & Limnephilidae & - & - & - & + \\
\hline 25 & Trichoptera & Hydropsychidae & Polycentropus & + & + & + & + \\
\hline 26 & Tricladida & Dugesiidae & Planaria & + & + & + & + \\
\hline
\end{tabular}


Table 4. Diversity index value of macrozoobenthos at each spring

\begin{tabular}{lrccc}
\hline Diversity Index & Demplot & Sumber Sempol & Alang-alang & Sumber Bendo \\
\hline Diversity indexShanon-Wiener (H') & 1,58 & 1,93 & 1,40 & 1,97 \\
Evenness Index (E) & 0,60 & 0,73 & 0,54 & 0,69 \\
Dominance Index (C) & 0,34 & 0,22 & 0,40 & 0,22 \\
Species Richness Index (DMg) & 2,28 & 2,28 & 2,10 & 2,81 \\
Species Density (K) & 369,24 & 679,41 & 1213,22 & 999,13 \\
\hline
\end{tabular}

Similar to previous study which stated that taxa abundance increases due to the rainy season includes Baetidae, Chironomidae, and Simuliidae [15]. The Baetidae family belongs to the Ephemeroptera group. It has a high level of sensitivity to pollution and generally requires clean water quality conditions, makes it an indicator of a clean river conditions [9].

The Sumber Bendo spring has the highest number of taxa during the study, which comprised 17 taxa. Meanwhile, the lowest number of taxa found in Alang-Alang spring with 13 species. Some species were only found in one location. In contrast, the species of Melanoides tuberculata and Planaria were species that can be found in all study locations (Table 3).

Based on the Shannon-Wiener index value, the four springs have a medium level of diversity with $\mathrm{H}$ values ranged from 1.40-1.97. This value indicated that the water quality of the four springs was moderate to mildly polluted contamination. Spring with moderate polluted quality was Alang-Alang spring with a diversity index between 1.0-1.5, while the other three springs have mild polluted quality with diversity values ranged 1.6-2.0. Spring with the highest diversity index was Sumber Bendo with a value of 1.97, which is close to the uncontaminated category. The uniformity and dominance index of the four springs showed that the spread of macrozoobenthos species tends to be evenly distributed. Thus, it can be concluded that no species dominated. The highest species richness was found in the Sumber Bendo, while the highest density of the macrozoobenthos species was found in Alang-Alang (Table 4).

Based on biotic index calculations, each produced a value with a different pattern. Based on the ASPT index (Fig. 4), Alang-Alang and Sumber Sempol springs showed uncontaminated water quality categories, with a value of more than 6. It was because in both springs found an intolerant macrozoobenthos family of contamination, such as Psephenidae, Heptageniidae, and Gerridae [21]. The Demplot and the Sumber Bendo fell into the category of mild polluted water quality, which has a value between 5-6 (Fig. 4).

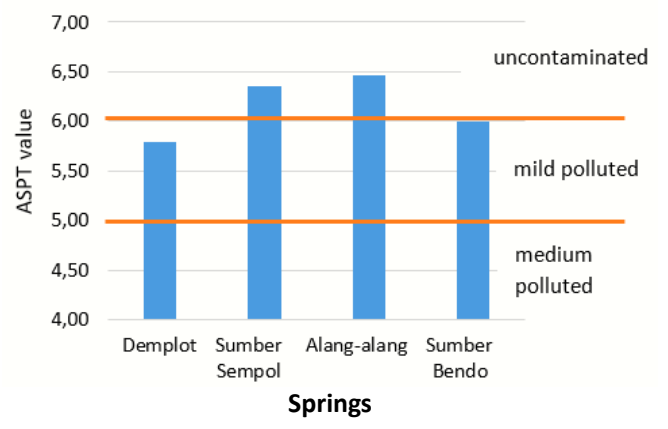

Figure 4. The value of ASPT and category of water quality in each spring

Water quality based on $\mathrm{FBI}$ values at all springs showed excellent quality with a value of less than 3.75 (Fig. 5). It showed that the level of pollution in all four springs was not polluted by organic matter. The low FBI value is because, in the four springs, there were found a lot of macrozoobenthos families with a low tolerance score of $0-4$, like Baetidae and Hydropsychidae. The presence of Hydropsychidae can be used as an indicator of good water quality [16]. Hydropsychidae larvae reported being very sensitive to heavy metal pollution, which was shown by respiratory system disorders by morphological changes in the larva gills. Gills blacken and decreased when exposed to heavy metals such as cadmium and aluminum [17].

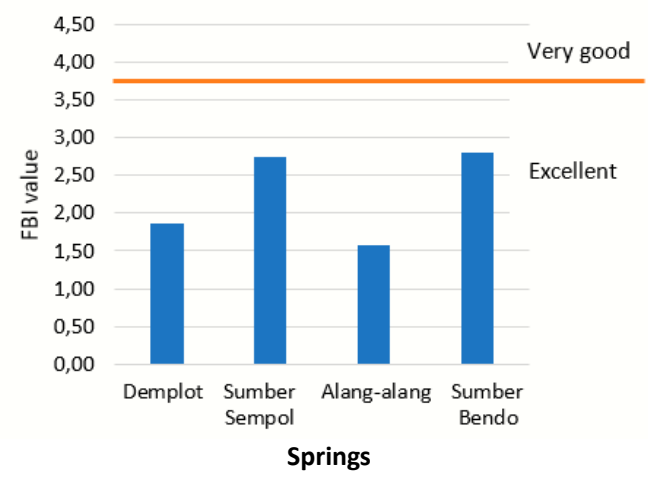

Figure 5. The value of $\mathrm{FBI}$ and category of water quality in each spring 


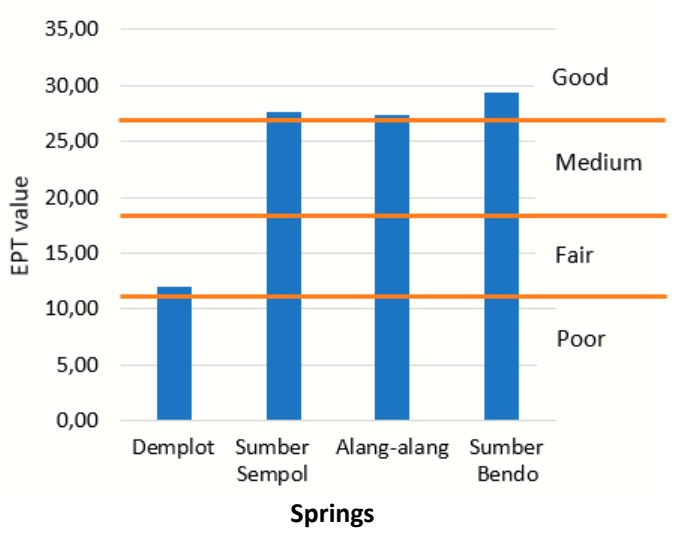

Figure 6. The value of EPT and the category of water quality in each spring

The highest EPT value was in the Sumber Bendo spring, then followed by Sumber Sempol spring, and Alang-Alang spring, which showed good water quality with values between 28-35. It was because of the three springs found in the type of macrozoobenthos, which belonged to the order Ephemeroptera and Trichoptera. The Ephemeroptera, Plecoptera, and Trichoptera (EPT) orders are sensitive to contaminants such as metals and insecticides [22]. The EPT order is usually in clean water with high DO [18]. The lowest value was calculated from the demplot spring, which is between 11-18 with sufficient water quality categories (Fig. 6).

\section{Water Quality Grouping in Four Wana Wiyata Widya Karya Springs}

The level of similarity in water quality in each location obtained from the Bray-Curtis index value. The parameters used were biotic index and physicochemical parameters in each spring. The results of cluster analysis based on biotic index and physicochemical parameters at the level of similarity $45 \%$ of the study locations were

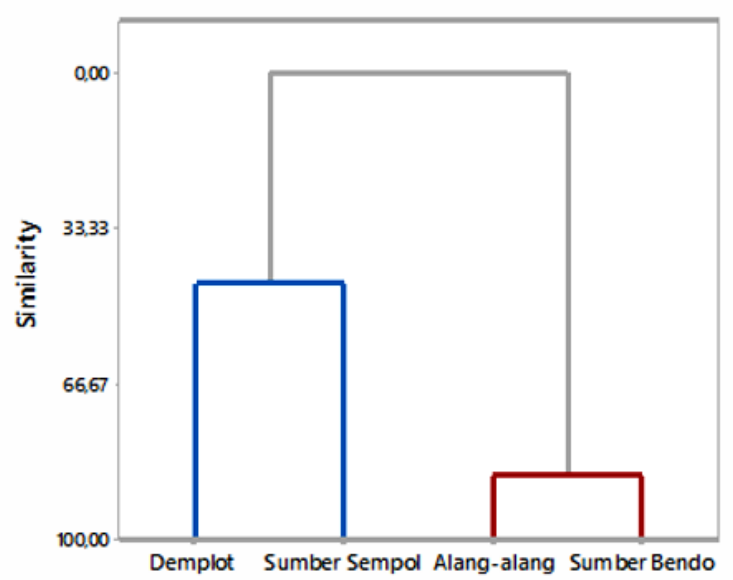

divided into two cluster groups, as shown in Figure 7. The first group contained Alang-Alang and Sumber Bendo springs, which did not have much difference with similarities of $86.49 \%$, while the Demplot spring and Sumber Sempol were in the other groups.

Formation of the two groups was supported by the biplot analysis results in Figure 7. AlangAlang and Sumber Bendo were in a group, due to their character of physicochemical parameter values, which almost has the same debit and $\mathrm{pH}$ so that both stations in the same quadrant. Then Demplot and Sumber Sempol springs formed another group characterized by almost the same conductivity value so that the two springs were in the adjacent quadrant. Based on the biplot analysis, the Demplot spring were in different quadrants characterized by high BOD values. Meanwhile, the springs in the other springs are characterized by the highest turbidity value compared to other springs.

\section{CONCLUSION}

Water quality in four springs at Wana Wiyata Widya Karya Tourism Area in Cowek Village based on the NSF Water Quality Index was in a good category, with a value between 72.7788.37. Based on Government Regulations No. 82 year 2001, some physicochemical parameters in the four springs met the class I water quality standard (BOD, DO, temperature, and $\mathrm{pH}$ ). Water quality based on the value of the macrozoobenthos diversity index indicated the category of moderate to mildly polluted contamination, with a value of $\mathrm{H}^{\prime}$ between 1.401.97. The Bray-Curtis similarity index results showed a high level of similarity in Alang-Alang and bendo sources of $86.49 \%$.

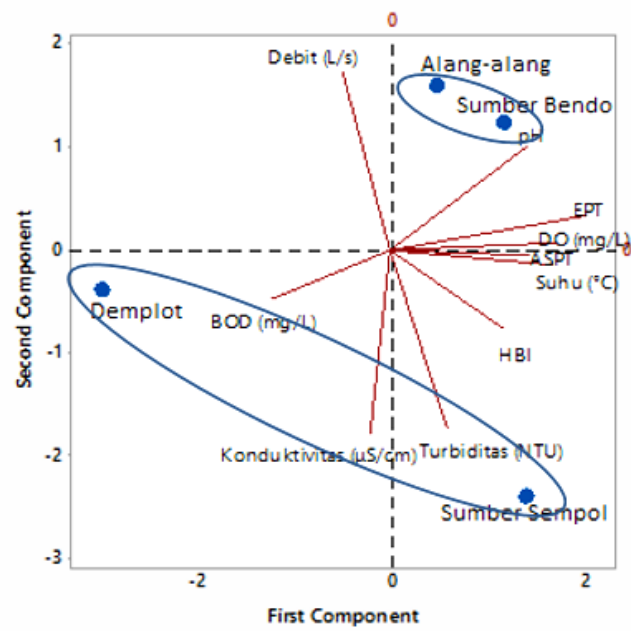

Figure 7. The level of similarity of cluster analysis based on biotic index and physicochemical parameters 


\section{Acknowledgement}

Thanks to Komunitas Si Hijau in Wana Wiyata Widya Karya who provided information and allowed the researchers to take samples. We also thank all of colleague and staff of Laboratory of Ecology and Animal Diversity, University of Brawijaya, Malang.

\section{REFERENCES}

[1] Hendrawan, D. 2005. Kualitas air sungai dan Situ di DKI Jakarta. Makarta Teknologi 9(1), 13-19.

[2] Krebs, C. J. 1989. Ecological methodology. Haper Collins Publishers. New York.

[3] Winarno, K., O. P. Astirin, and A. D. Setyawan. 2000. Pemantauan kualitas perairan Rawa Jabung berdasarkan keanekaragaman dan kekayaan komunitas bentos. Jurnal Biosmart 2(1), 40-46.

[4] Ott, W. R. 1978. Environmental indices theory and practice. Ann Arbor Science Publisher Inc. Washington DC.

[5] Brower, J. E., J. H. Zar, and C. N. von Ende. 1990. Field and laboratory methods for general ecology. WCB Publishers. Dubuque.

[6] Odum. E. P. 1993. Dasar-dasar Ekologi, $3^{\text {rd }}$ Ed. UGM Press. Yogyakarta.

[7] Taqwa. 2010. Analisis produktivitas primer fitoplankton dan struktur komunitas fauna makrobenthos berdasarkan kerapatan mangrove di Kawasan Konservasi Mangrove dan Bekantan Kota Tarakan, Kalimantan Timur. Master Thesis. Diponegoro University. Semarang.

[8] Mason, C. F. 1991. Biology of freshwater pollution. Longman, Inc. New York.

[9] Arisandi, P. 2012. Studi kualitas air Sungai Bone dengan metode biomonitoring (online). Proceeding of Chemistry National Seminar. State University of Surabaya. 298309.

[10] North Carolina Department of Environment, Health, and Natural Resources [NCDEHNR]. 1997. Standard operating procedures for biological monitoring. Environment Sciences Branch Biological Assessment Group. Division of Water. Water Quality Section.

[11] Barus, T. A. 2002. Pengantar limnologi. Directorate of State Higher Education. Jakarta.

[12] Aisyah, S. and Sugiarti. 2010. Pendekatan analisis multivariat dalam menentukan sebaran spasial karakteristik kualitas air dan substrat sedimen di Danau Towuti. Limnotek $17(2), 218-226$.
[13] Effendi, H. 2003. Telaah kualitas air bagi pengelolaan sumberdaya dan lingkungan perairan. Kanisius. Yogyakarta.

[14] Effendi, H. 2015. Simulasi penentuan Indeks Pencemaran dan Indeks Kualitas Air (NSFWQI). Formulasi IKLH. Puslitbang Kualitas dan Laboratorium Lingkungan. KLHK. Jakarta.

[15] Robinson, C. T., U. Uehlinger, and T. M. Michael 2003. Effects of a multi-year experimental flood regime on macroinvertebrates downstream of a reservoir. Aquatic Sciences 65(3), 210-222.

[16] Stuijfzand, S. C., S. Engels, E. V. Ammelrooy, and M. Jonker. 1999. Caddisflies (Trichoptera: Hydropsychidae) used for evaluating water quality of large European rivers. Archieves Environmental Contamination Toxicology 36, 186-192.

[17] Sudarso, Y. 2009. Potensi larva Trichoptera sebagai bioindikator akuatik. Oseanologi dan Limnologi di Indonesia 35(2), 201-215.

[18] Cavallaro, K. O. R., M. R. Spies, A. E. Siegloch. 2010. Ephemeroptera, Plecoptera, Trichoptera assemblages in Miranda River basin, Mato Grossodo Sul State, Brazil. Biota Neotropica 10(2), 253-260.

[19] Reublic of Indonesia. 2001. Government Regulation No. 82 year 2001 about water quality management and control of water pollution. Rpublic of Indonesia. Jakarta.

[20] Kurniawan, A. 2014. Identifikasi kualitas air berdasarkan nilai resistivitas air, studi kasus : Kali Gajahwong. Department of Environment Geography. Faculty of Geography. Gadjah Mada University. Yogyakarta.

[21] Arthana, I W. 2012. Studi kualitas air beberapa mata air di sekitar Bedugul, Bali (The study of water quality of springs surrounding Bedugul, Bali). Bumi Lestari 7(1), 1-9.

[22] Furaidah, Z. and C. Retnaningdyah. 2013. Perbandingan kualitas air irigasi di pertanian organik dan anorganik berdasarkan sifat fisiko-kimia dan makroinvertebrata bentos, studi kasus di Desa Sumber Ngempoh, Lawang Kabupaten Malang. Jurnal Biotropik 1(4), 154-159. 